\title{
Analysis of Merger and Acquisition in Pakistan
}

\begin{abstract}
Majeedullah Khan', Safiullah Khan', Muhammad Faisal Rizwan ${ }^{3}$
${ }^{1}$ Kohat University of Science and Technology, Kohat Pakistan

${ }^{2}$ Universiti Teknologi Brunei, Brunei Darussalam

${ }^{3}$ Assistant Professor, Faculty of Management Sciences, International Islamic University, Islamabad

\section{A B S T R A C T}

We examine financial performance of firms in the post-Merger and acquisition period for firms listed on the Karachi Stock Exchange by exploring various motives of merger and acquisitions offered by theoretical and empirical literature. Specifically, we explore these motives in the context of the theory of synergy, agency theory and behavioral finance perspectives. Empirical results for agency theory shows the presence of empire building motives that lead to the underperformance of firms in post-merger and acquisition period. The study finds no support for managerial risk aversion hypothesis of agency theory in Pakistani market. Empirical results do not find any evidence to support the presence of managerial hubris or overconfidence proposition but we do find evidence in support of the escalation of commitment hypotheses and its impact on postmerger and acquisition performance.
\end{abstract}

KEYWORDS: Merger and acquisition (M\&A), Empire Building, Managerial Risk aversion, Hubris, Escalation of commitment

\section{INTRODUCTION}

Merger and acquisitions (M\&As) are primarily used as a growth strategy by firms. Although, there are many ways of achieving growth for firms such as organic growth, joint ventures and strategic alliance, the basic motive behind M\&A is to increase profitability, achieve rapid growth and a fast way to capture market share. Several studies have been conducted on the effects of M\&A across markets and this vast body of literature offers varying results. These conflicting results are the the output by employing different methodologies, using different measurement proxies for operating performance and other variables. Besides, there are theoretical underpinnings for these different and conflicting results. Little attention has been paid to analyze the motives that stem from 
agency theory and behavioral finance perspectives and its impact on M\&A results. This paper examines different motives for which firms undertake merger and acquisitions utilizing data from an emerging market like Pakistan. First, we conduct post-merger versus pre-merger financial performance of acquiring firms. Second, we explore the possibility of agency problems such as empire building, managerial risk aversion, and its impact on the performance of firm's post-M\&As. Third; we also explore behavioral motives such as managerial hubris (overconfidence) and escalation of commitment and its impact on post-M\&A performance of firms.

We examine mergers and acquisitions data from Pakistan's market utilizing 18year data from 1995 to 2013. We examine these M\&As to explore motives behind these mergers from different perspectives including agency theory, synergy theory and from behavioral perspectives. Our results contribute to the literature in several ways. First, our results confirm the growing concerns of many studies that mergers can involve multiple motives as we find support for the agency theory motives as well as for the behavioral motives for mergers. Second, we contribute to the literature by exploring developing market for mergers, especially in terms of behavior motives for mergers since it is a relatively unexplored area, particularly in developing markets. Our results contribute to this area since we find support for the escalation of commitment hypothesis in postmerger performance. Lastly, our results are based on ex-post firm performance and are consistent with prior studies that are based on the pre-acquisition information.

The remainder of the paper is organized as follows. Next section provides a review of relevant literature and hypotheses while section 4 details methodology and data analysis while las section concludes the paper.

\section{LITERATURE REVIEW}

Economic gains from corporate acquisitions can be explained by theoretical underpinnings that elaborate the reasons for post-merger economic gains. These theories are neo-classical economics, theory of synergy and free cash flow theory.

The theoretical rationale for Mergers \& Acquisition is based on the Neo-classical theory (Weintruab, 2002) that postulates that people have rational preferences between outcomes that can be associated with values. According to this theory, M\&A is only 
justifiable when it results in synergies and increases the wealth of shareholders. M\&A transactions will be only creating value if firm's combined worth is more than as separate entities (Brealey, Myers and Allen, 2008). On the other hand, the theory of synergy suggests that M\&A transactions create value due to similarities in resources amongst merging firms. All overlapping activities are eliminated to save cost. On the other hand, unique valuable synergy might be created due to differences that exist between the resources of the target and acquiring firms (Linn \& Switzer 2000). The value creation in M\&A transitions is either due to a decrease in cost in post mergers period or increase in sales and charging higher prices. Broader classes of resources that contribute to value creation in M\&A are the cost of capital (financial synergy), cost of production (operational synergy) and price related (collusive synergy). Financial synergy contributes more to value creation in M\&A than operating synergy (Chatterjee, 1992).

Whether M\&As do create value for shareholders is more of an empirical question to examine post-merger financial performance. Findings of some studies show that M\&A have a positive impact on firm's financial performance (Ismail, Abdou \& Annis, 2010); Lau, Proimos\& Wright, 2008; Ramaswamy and Waegelein, 2003), and positive stock returns (Ghosh 2001). Mergers in banking industry also show a positive relationship with value creation for both bidder and target stock (Houston, James, and Ryngaert, 2001).

Some studies report contrasting results and reveal that firms show poor performance after M\&As transactions. Accounting profitability measurement revealed that M\&A have a negative impact on the wealth of shareholders (Ravenscraft \& Scherer, 1987; Pazarskis, Vogiatzogloy, Christodoulou \& Drogalas (2006), and Yeh and Hoshino (2002). Measures of corporate performance provide mixed results such as asset turnover shows a significant gain in the longer term. Fatma and Shehzad (2014) study the bank's mergers in Pakistan and report that RoE is affected by M\&A. Rodiel (2013) finds that M\&A have a significant negative relationship with return on equity (ROE).

In summary, the findings are mixed for post-merger gains. It is evident that there is no conclusive evidence of value creation after mergers and acquisitions. Some studies show that merger, on average, does not create value for shareholders. In some cases, gains are either negligible or non-existent while other studies document positive gains in 
firm performance after merger and acquisitions. Based on the above arguments and empirical evidence, we formulate the following hypothesis.

\section{H1: Post-merger and acquisition operating performance of the firms is greater than the pre-merger and acquisition performance.}

Jensen's (1986) theory of free cash flow posits that firms with excess cash flows have an incentive to indulge in sub-optimal investment decisions and that, consequently, may decrease firm value for shareholders. Jensen (1986) argues that free cash flows exacerbate agency problem when firms have little growth prospects and have a high level of free cash flow and firms consider financing the acquisitions with shares instead of cash.

Servaes (1991) documents that cash acquisition creates debt in the event and reduce managers' freedom to use free cash flows. The strong covenants and fixed interest charges are checks on managers' performance and compel them to be efficient. Roll (1986) argues that one of the major causes of taking over activities is agency cost that arises from the conflicts on free cash flows between managers and shareholders.Managers are motivated to work in large organizations that ensure job security, control over resources and high compensation (Murphy, 1985). Hence, managers with free cash flows are prone to acquire another firm for personal motives and that may be to increase the size of the firm or risk aversion (Jovanovic \& Braguincky, 2002).

Firms with a high level of free cash flows are more prone to agency problems and tend to over-invest (Jensen, 1986; Abdullah, Shah, and Khan, 2012). Free cash flow hypothesis argues that managers with little profitable investment opportunities and high level of free cash flows pursue personal motives such as empire building and undertake sup-optimal acquisitions (Jensen, 1986). Thus, we expect that firms that are large and have high levels of excess cash are more likely to indulge in corporate acquisitions. Sharma and Ho (2002) find that acquisitions are motivated by management self-interest rather than for the best interest of the shareholders. On the basis of above literature, we postulate the following hypothesis.

H2: Free cash flow prior to acquisition negatively affects post-M\&A performance Risk 


\subsection{Aversion and Diversification Strategies}

Risk exposure of the acquiring company is influenced by M\&A strategy and it depends on the type of acquisition. If such strategy fails, it will result in a risk of unemployment for managers (Brealey et al. 2008). When there are multiple possibilities of M\&A then managers may favor safe over risky M\&A even in case the risky one might yield a higher return. The risky M\&A transaction may put the job of managers at risk. Consequently, they would attempt to avoid risky M\&A.

In a single company, managers are exposed to risk and their risk is undiversified. In such a case if the business performs badly managers, face a higher risk of job loss. To mitigate these risk managers diversify the business through M\&A. Sudarsanam (2003) argues that conglomerate mergers have value maximizing reasons like increase in market power, efficient internal capital and transfer pricing. On the other hand, managers favor diversification strategy for their job security and this, in turn, may provide reasons for value destroying in M\&A activities. Thus, it is not in the interest of shareholders when managers pursue diversification strategy in M\&A transaction on personal motives (Brealeyet al.2008).

Morck, Shleifer, and Vishny (1990) find that unrelated M\&A underperforms. Similar results are also reported by Berger and Ofek (1995) and Doukas, Holmen and Travlos (2001). In contrast, Ghosh (2001) and Kruse, Park, and Suzuki (2003) document that unrelated M\&As outperform their peers. Based on these mixed results we develop the following hypothesis.

\section{H3: There is no difference between post-M\&As' operating performance of related} M\&As and Unrelated M\&As.

\subsection{Behavioral Finance and Mergers \& Acquisitions}

We also examine M\&As activity from behavioral finance perspective with an objective to explore manager's behavioral motives for undertaking M\&As activities. Shefrin (2007) affirms that behavioral phenomena may also tempt managers to act against shareholders' interest since such behavioral costs may arise because of managers' mistakes and consequently it can add to the understanding of underperforming M\&As. 
Managerial biases, such as overconfidence, disposition effect, and loss aversion, and its impact are studied theoretically and empirically in many areas of corporate finance including merger and acquisition (Ben-David, Graham \& Harvey 2007).

Managers often make financial projections that are used as inputs to formulate corporate policies. Human judgments are subject to biases such as overconfidence or managerial hubris and affect the decision-making process. Psychological evidence reveals that manager exhibits overconfidence in predictions and it occurs due to overestimation of their ability to predict future benefits (Ben-David, Graham \& Harvey, 2007). Hubris is reflected in M\&A transaction when management overpays in two situations. First, they are optimistic about the potential value of synergies they are going to acquire and, secondly, are overconfident about their ability to manage acquisitions (DePamphilis, 2008). Hribar and Yang (2013) argue that overconfidence of manager is a miscalculation of their judgment and they tend to overestimate their abilities in decisionmaking.

When there are many bidders for one target the hubris affects the winning bidders and are likely exposed to winning curse, which, in turn, overvalue target firm without fully assessing the real value and potential synergies of target firm (Roll, 1986). If the target firm roughly has the same value for all bidders in competition then there are chances that winning bidder may overstate the gain of takeover (Brealey et al 2008). Managers who suffer from hubris are more likely to win the bid and overpay for potential synergies (Malmendier \& Tate, 2008). Malmendier and Tate (2008) find that overconfident CEOs overestimate their ability to generate returns on their mergers and that these CEOs overpay for the merger transactions. Nguyen, Yung, and Sun (2012) used Tobin $\mathrm{Q}$ as a proxy for managerial hubris and find the positive relationship of Tobin's Q with mergers and the result is consistent with the view that managers involved in mergers for their own hubris satisfaction.

We can deduce that managers overestimate their abilities to manage M\&A. Malmendier and Tate (2008) reveal that availability of internal funds and unused debt capacity augmented the overconfidence of managers in acquisitions of firms. Sharma and Ho (2002) also confirm hubris hypothesis in their study on Indian firms. Unutilized debt 
capacity is measured by debt to equity ratios and used as a proxy for overconfidence of managers.

Several factors could foster overconfidence. Theory suggests that people rely on readily available information in human mind in their decision-making process and if firms have outperformed prior to the acquisition or have unutilized debt capacity, it will enhance overconfidence of managers to acquire other firms. Roll (1986) also argues that bidders who have experienced recent good time in pre-bidding period will pursue the target aggressively due to hubris. Based on the literature reviewed, we formulate the following hypothesis:

\section{H4. Unutilized Debt capacity of acquirer firms before M\&A affects negatively post} mergers performance.

\subsection{Loss Aversion and Escalation of commitment}

Loss aversion means that people feel the pain of loss more than the joy of gain of the same magnitude. Psychologically, loss aversion leads to regret avoidance. Bazerman and Moore (2009) report that regret avoidance can result in decisions that are more irrational when managers make decisions with the mindset to avoid losses. Specifically, in M\&A the loss aversion is relevant for research when it leads to an escalation of commitment to the transaction. This is a classic example of throwing good money after bad. Shefrin (2007) documented that managers spend more money on failure for they feel responsible while in success case no feeling of a sense of achievement.

Acquisition of any firm seems to be attractive but management may expose to the escalation of commitment. When M\&A is publicized then chances of escalation of commitment increases. Manager's tendency to the escalation of commitment increases in such a case due to reputational reasons. (Bazerman\& Moore 2009). This can be explained by disposition effect where managers lead to overinvestment in underperforming M\&A. Consequently, managers will increase investment level if they suffered from the escalation of commitment. Thus examining the investment level pre and post-acquisition will provide evidence of this bias. Hence, we develop the following hypothesis:

H 5: M\&A that experience increase in post-M\&As capital expenditure overperforms with respect to other $M \& A s$. 


\section{RESEARCH METHODOLOGY}

We used univariate analysis and multivariate regression specifications to test the hypotheses formulated in the previous section and to examine post- versus pre-M\&As performance.

First, we use univariate analysis for a mean difference of variables for pre- versus post-merger performance implying t-statistic to test the hypotheses. Despite the limitation of univariate (change model) it has been widely used in literature to examine the post M\&A performance of the firms such as Healey et al (1992), Switzer (1996), Sharma and Ho (2002), Pazarskis et al (2006), Usman et al (2005), Sinha, Kaushik and Chaudhary (2010), Karla (2013), and Fatma and Shehzad (2014). The downside of univariate analysis is that it only provides a single mean difference of a variable and does not explain reasons for such changes. Hence, we also use multivariate analysis to explore the relationship between the selected proxies of variables.

\subsection{Operating Performance}

\subsubsection{Agency Motives and Merger \& Acquisitions}

We use the following models to test hypotheses 2 and 3. For

Empire Building motive:

$Y_{\text {POST }, i}=\alpha_{0}+\beta_{1}$ FCF $_{i}+\beta_{2}$ TANG $_{i}+\beta_{2} S_{I Z E_{i}}+\beta_{3} S A L E G R W T H_{i}+\varepsilon_{I}---$ $---(1)$

For Managerial Risk Aversion motive:

$$
\begin{gathered}
Y_{\text {POST }, i_{i}}=\alpha_{0}+\beta_{1} \text { RELTD }_{i}+\beta_{2} \text { TANG }_{i}+\beta_{2} \text { SIZE }_{i}+\beta_{3} \text { SALEGRWTH }_{i}+\varepsilon_{I}-- \\
---(2)
\end{gathered}
$$

Where $Y_{\text {Post, } i}$ is post-merger performance (ROA \& ROE) of the $i^{\text {th }}$ firm while FCF is the free cash flow calculated as Earnings Before Interest, Taxes, Depreciation and Amortization (EBITDA) minus Capital Expenditures and then divided by total assets. We use this variable as a proxy for empire building motive. Control variables are tangibility (GANG) measured as property, plant and equipment divided by total assets, sales growth (SALEGRWTH) measured as Current year sales divided by previous year sales, and SIZE shows the size of target firm with respect to the acquirer. In equation (2), RELTD is a dummy variable that takes the value of 1 if the mergers and acquisition transaction is in 
not in the same industry and zeroes otherwise.

\subsubsection{Behavioral Finance and Mergers \& Acquisitions}

The following two models test the impact of overconfidence and escalation of commitment on post-merger performance, respectively:

$$
\begin{gathered}
Y_{\text {POST }, i_{i}}=\alpha_{0}+\beta_{1} \text { DTEQTY }_{i}+\beta_{2} \text { TANG }_{i}+\beta_{2} \text { SIZE }_{i}+\beta_{3} \text { SALEGRWTH }_{i}+\varepsilon_{I} \\
-----(3)
\end{gathered}
$$

Escalation of Commitment motive:

$$
\begin{gathered}
Y_{\text {POST }, i_{i}}=\alpha_{0}+\beta_{1} \triangle C A P E X_{i}+\beta_{2} \text { TANG }_{i}+\beta_{2} \text { SIZE }_{i}+\beta_{3} \text { SALEGRWTH }_{i}+\varepsilon_{I} \\
-----(4)
\end{gathered}
$$

Where $Y_{\text {Post, } i}$ is post-merger performance (ROA \& ROE) of the $i^{\text {th }}$ firm, $D T E Q T Y_{i}$ is the debt-equity ratio of the Acquirer firm prior to M\&A. We use this ratio as a proxy for overconfidence motive. Control variables are tangibility (TANG), sales growth (SALEGRWTH) and size of the target with respect to the acquirer. In equation (4), ( $\triangle \mathrm{CAPEX)} \mathrm{represents} \mathrm{changes} \mathrm{in} \mathrm{capital} \mathrm{expenditures} \mathrm{after} \mathrm{M \& As,} \mathrm{and} \mathrm{it} \mathrm{is} \mathrm{a} \mathrm{proxy}$ for escalation of commitment motive.

We follow Powell \& Stark (2005), and use Return on Assets (ROA) and return on equity (ROE) for measuring operating performance. Firm-specific accounting measures of performance are preferable over event study approach that is based on analysis of stock price returns that measure investor expectations about firm's future performance instead of reflecting real economic value. The study examines the effect of agency related motives (empire building, and managerial risk aversion) and motives related to behavioral finance (Overconfidence, and escalation of commitment) on performance on firms after merger and acquisitions.

\subsubsection{Measurement of Control variables}

Dimson and Marsh (1986) and Agarwal, Jaffe, and Mandelker (1992) suggest that adjustment for firm size is important to study long-term performance of firms since acquirers are usually large firms. Linn and Switzer (2001) argue that large size of target firms in M\&A transactions results in economies of scale and other synergies. Linn and Switzer (2000) incorporated relative size of firms and method of payment as a control variable in his cross sectional model. Consequently, we use firm size (natural log of 
assets) as a control variable in regression estimation.

Firms' performance, like ROA and Tobin's Q, are influenced by the level of asset tangibility (ratio of fixed assets to the total asset) (Mishra, Randoy \& Jenssen, 2001). Randoy and Goel (2003) find that size positively affects firms' performance. We also use tangibility as a control variable in our regression estimation.

\section{Data}

Unit of analysis for this study is M\&A transactions and its effects on firm performance measured by accounting return adjusted to industry averages. The list of mergers that took place during the period 1995 to 2013 is available on Karachi Stock Exchange (KSE) websites (www.kse.com.pk). We start our sample from 1995 because KSE started reporting M\&A transactions since 1995. For comparable result with prior studies (Sharma \& Ho, 2002, Healy et al, 1992) the sample firms were grouped into financial and non-financial firms. Out of a total of 124 acquisitions, 27 transactions were excluded due to unavailability of data for three years either pre or post acquisitions date. The final sample consists of 96 firms. This sample size of 96 acquisitions is justifiable given that some prior studies have used smaller samples such as 50 firms (Healy et al, 1992), 30 firms (Kumar, 2009; Trivedi, 2013) and 47 companies (Karla, 2013). We follow Sharma \& Ho (2002), Linn and Switzer (2001) and Parino and Harris (1999) and use three-year window pre- and post-M\&A period to examine post-merger financial performance. Further, year in which acquisition took place is excluded from our analysis. Firm specific accounting variables such as total assets (T.A), Capital Expenditures (Capex), and debt were sourced from the annual reports of firms and from the State Bank of Pakistan (SPB) archives and its website.

\section{Data Analysis: Univariate tests}

Comparing three years mean ROA pre- versus post-Merger and Acquisition it reveals that M\&A shows negative ROA but statistically insignificant as shown in Table 1 (Panel A). So we fail to accept the hypothesis H1. There is a statistically insignificant decrease in ROA after M\&A. 


\begin{tabular}{|c|c|c|c|}
\hline \multicolumn{4}{|c|}{$\begin{array}{l}\text { Table 1( Panel A): Mean of Return on Assets (ROA) for Merger \& Acquisition in } \\
\text { periods during 1995 - } 2013\end{array}$} \\
\hline Years Relative Mergers & $\begin{array}{l}\text { Average } \\
\text { ROA }\end{array}$ & $\begin{array}{c}\text { No. of } \\
\text { Observations }\end{array}$ & Sig. two-tailed \\
\hline Annual Mean ROA for years -3 to -1 & 0.0986 & 96 & \\
\hline Annual Mean ROA for years +1 to +3 & -0.0018 & 96 & \\
\hline Mean Difference & $(0.1162)$ & 95 & 0.297 \\
\hline \multicolumn{4}{|c|}{$\begin{array}{l}\text { Table } 1 \text { (Panel B): Mean of Return on Equity (ROE) for Merger \& Acquisition in } \\
\text { periods during 1995 - } 2013\end{array}$} \\
\hline Years Relative Mergers & $\begin{array}{l}\text { Average } \\
\text { ROE }\end{array}$ & $\begin{array}{c}\text { No. of } \\
\text { Observations }\end{array}$ & Sig. two-tailed \\
\hline Annual Mean ROE for years -3 to -1 & 0.1602 & 96 & \\
\hline Annual Mean ROE for years +1 to +3 & 0.0092 & 96 & \\
\hline Mean Difference & $(0.1510)$ & 95 & $0.086^{*}$ \\
\hline
\end{tabular}

Table I (Panel A) shows that firm's performance becomes worsen after M\&A as compared to pre-M\&A performance. Using paired-sample test, the result shows that ROE decreases significantly at $10 \%$ level after M\&A (see Table 1 (Panel B). It is evident that M\&A transactions have a significant impact on firm's performance. During post-merger periods ROE decline by $15 \%$ approximately as compared to pre-merger period. Thus, there is some evidence to reject the hypothesis (H1) that post-merger and acquisition (M\&A) performance of the firms is greater than the pre-merger and acquisition (M\&A) performance. The result of this study are consistent with other studies on post M\&A's performance conducted in the USA (see Gosh, 2001), Australia (see Sharma \& Ho, 2002), Greece (See Pazarskis et al, 2006), Pakistan (See Usman et al., 2005, Fatma \& Shahzad, 2014), India (see Mantravadi\& Reddy, 2008, Kumar, 2009, Karla, 2013), to mention few studies. These results are contrary to theories of neoclassical economics and theory of synergy which propagates that post-M\&A performance increased. The negative changes in performance (ROA \& ROE) cannot be associated solely with M\&A deal. There are some other factors that affect post-merger performance such as agency issues and managerial hubris. Further investigations are carried out in the following section of this chapter for value destroying M\&A in Pakistani market. 


\section{Agency Motives and Post-Merger Financial Performance}

We further examine under-performance of firms in the post-merger period by exploring the agency motives for M\&As activities. We employ independent sample test for examining empire building motives in M\&A and results show that under-performer firms have high pre-M\&A free cash flows as compared to outperformers. In Table 2 panel $\mathrm{A}$, mean difference of acquirers free cash flow (pre-M\&A) is significant at $1 \%$ level. In other words, those firms engage in M\&A having high free cash flows significantly underperform in terms of ROA., though it statistically insignificant. Univariate analyses accept the second hypothesis that free cash flow prior to M\&A negatively affects post-M\&A performance. These results are in line with some previous studies. Similar conclusions are also drawn in earlier studies such as Sharma and Ho (2002) and Jensen (1986).

\begin{tabular}{|c|c|c|c|}
\hline Particulars & Underperforming & Outperforming & Sig. 2-tailed \\
\hline Acquirer's pre-Free Cashflow & 0.1091 & -0.1015 & \\
\hline No. of Observations & 40 & 56 & \\
\hline Mean Difference & \multicolumn{2}{|c|}{-0.2105} & $0.012 * * *$ \\
\hline \multicolumn{4}{|c|}{ Panel B: Return on Equity (ROE) } \\
\hline Particulars & Underperforming & Outperforming & Sig. 2-tailed \\
\hline Acquirer's pre-Free Cashflow & 0.0257 & -0.0335 & \\
\hline No. of Observations & 32 & 64 & \\
\hline Mean Difference & \multicolumn{2}{|c|}{-0.0591} & 0.456 \\
\hline
\end{tabular}

We further examine the possibility of empire building motive in a multivariate analysis by examining pre-M\&A free cash flow on post-M\&As performance employing equation (1), and results are shown in Table 3 (Panel A). The Table reports that premerger free cash flow of acquirers do not affect post-M\&A ROA as shown by statistically insignificant coefficients. However, ROE (Table 3-Panel B) shows that coefficient of pre-M\&A free cash flow is negative and statistically significant at $10 \%$ level which implies that pre-M\&A free cash flow negatively affects post-M\&A ROE (performance) which supports the existence of empire building motive of management that may lead to less optimal mergers. This suggests that management of those firms, 
having a high level of free cash flow before M\&A, will indulge in such motives as empire building and consequently lead to underperforming merger deals.

\begin{tabular}{|c|c|c|}
\hline Dependent Variable: Return on Assets (ROA) & Coefficient & p-values \\
\hline Intercept & -1.785 & $0.006^{* * *}$ \\
\hline Free Cash flow & .087 & 0.390 \\
\hline Size of Acquisition & 053 & 0.652 \\
\hline Tangibility & .274 & $0.008^{* * *}$ \\
\hline Sales Growth & .017 & 0.887 \\
\hline Adjusted $\mathbf{R}^{2}$ & Significance $\mathbf{F}$ & $\mathrm{n}$ \\
\hline 0.050 & $0.069^{*}$ & 96 \\
\hline \multicolumn{3}{|l|}{ Table 3 (Panel B): Empire Building } \\
\hline $\begin{array}{l}\text { Dependent Variable: Return on Equity } \\
\text { (ROE) }\end{array}$ & Coefficient & p-values \\
\hline Intercept & 1.307 & $0.006^{* * *}$ \\
\hline Free Cash flow & -0.179 & $0.062^{*}$ \\
\hline Size of Acquisition & -0.308 & $0.007^{* * *}$ \\
\hline Tangibility & -0.230 & $0.019 * *$ \\
\hline Sales Growth & 0.263 & $0.019^{* * *}$ \\
\hline Adjusted R $^{2}$ & Significance $F$ & $\mathrm{n}$ \\
\hline 0.147 & $.001 * * *$ & 96 \\
\hline
\end{tabular}

Since the regression coefficient of the main variable is both economically and statically significant, thus hypothesis 2 is accepted. This supports free cash flow theory which states that large free cash flows and unutilized debt capacity may lead managers to underperforming merger deals (Jensen, 1986). The motive behind managers' investment in acquisitions of firms is to increase the firm's size. The larger the free cash flow the more tendency of managers to invest it in underperforming mergers and acquisitions. Similar conclusions are also drawn by Martynova and Renneboog (2006) provide evidence about free cash flow utilization for empire building and consequently, the firms fail to improve post-merger performance.

\section{Risk Aversion and Diversification Strategies}

Related M\&As do not diversify the risk of firms that are engaged in M\&A transactions while unrelated M\&As diversify the risk. To examine that related or 
unrelated M\&As impact on post-M\&A performance, we carry out independent sample tests as shown in Table 4. The test reports that both ROE and ROA are higher for unrelated M\&A but the mean difference is statistically insignificant and hence fail to reject the third hypothesis that there is no difference between the post-M\&As' performance of related and unrelated M\&A.

Table 4: Managerial Risk Aversion: Panel A: Return on Assets (ROA)

\begin{tabular}{|l|c|c|c|}
\hline \multicolumn{1}{|c|}{ Particulars } & Unrelated & Related & Sig. 2-tailed \\
\hline Post M\&A Return on Assets (ROA) & 0.1001 & -0.1016 & \\
\hline No. of Observation & 40 & 56 & \\
\hline Mean Difference & \multicolumn{2}{|c|}{-0.2017} & 0.284 \\
\hline
\end{tabular}

Panel B: Return on Equity (ROE)

\begin{tabular}{|l|c|c|c|}
\hline \multicolumn{1}{|c|}{ Particulars } & Unrelated & Related & Sig. 2-tailed \\
\hline Post M\&A Return on Equity (ROE) & 0.0990 & -0.0549 & \\
\hline No. of Observations & 40 & 56 & 0.289 \\
\hline Mean Difference & \multicolumn{3}{|c|}{-0.1539} \\
\hline *** Significant at 1\% level, ** Significant at 5\% level, * Significant at 10\% level \\
\hline
\end{tabular}

Table 5 reports results of the multivariate analysis to test risk-aversion hypothesis, employing equation (2). There is a positive relationship between ROA and unrelated M\&A and same for ROE but statically insignificant. The post M\&As performance when relating to sector-specific relatedness the result shows that mergers' performance is not affected significantly by relatedness or un-relatedness. In other words, post-M\&A performance of firms is not affected by either the acquirer acquired the target in the same business or in an unrelated business.

\begin{tabular}{|c|c|c|}
\hline Dependent Variables: Return on Assets (ROA) & Coefficient & p-values \\
\hline Intercept & -1.816 & $0.005^{* * *}$ \\
\hline RELTD & 0.097 & 0.348 \\
\hline Size of Acquisition & 0.085 & 0.485 \\
\hline Tangibility & 0.259 & $0.013^{* * *}$ \\
\hline Sales Growth & 0.010 & 0.933 \\
\hline Adjusted $\mathbf{R}^{2}$ & Significance $F$ & $\mathbf{n}$ \\
\hline 0.052 & $0.065^{*}$ & 96 \\
\hline \multicolumn{3}{|l|}{ Table 5 (Panel B): Managerial Risk Aversion } \\
\hline Dependent Variables: Return on Equity (ROE) & Coefficient & p-values \\
\hline Intercept & 1.250 & $0.010^{* * *}$ \\
\hline
\end{tabular}




\begin{tabular}{|c|c|c|}
\hline RELTD & 0.058 & 0.560 \\
\hline Size of Acquisition & -0.304 & $0.011^{* *}$ \\
\hline Tangibility & -0.226 & $0.024 * *$ \\
\hline Sales Growth & 0.260 & $0.023 * *$ \\
\hline Adjusted $\mathbf{R}^{2}$ & Significance $\mathbf{F}$ & $\mathbf{n}$ \\
\hline 0.117 & $0.004^{* * *}$ & 96 \\
\hline
\end{tabular}

Our result is consistent with earlier studies such as Sharma \& Ho (2002) studied Australian's firms and concluded that sensitivity test does not confirm significant impact of conglomerate/ nonconglomerate and sectors related/unrelated M\&A on post-merger performance.

We have not sufficient evidence to reject hypothesis developed in an earlier section that there is no difference between post-M\&As' operating performance of related M\&A and Unrelated M\&A. Findings of the study do not support that managers of the sample (merged) firms are risk averse and they undertake M\&A for diversifying reasons to reduce the risk and destroy the value for shareholders.

\section{Behavioral Motives and Post-Merger Financial Performance}

Behavioral motives that may stimulate mergers and acquisition are managerial hubris (overconfidence) and escalation of commitment. Statistical results for heuristics that biases decisions of managers engaged in M\&A are shown in Table 6 and 7 (overconfidence) and Table 8 (escalation of commitment).

\section{Managerial Hubris}

Independent sample test shows that low debt to equity $(\mathrm{D} / \mathrm{E})$ ratio (unutilized debt capacity of acquirer firms used as a proxy for managerial hubris) may lead to underperforming $\mathrm{M} \& \mathrm{~A}$ while firms having high $\mathrm{D} / \mathrm{E}$ ratio perform better. But mean difference is statistically insignificant as shown in panel A of Table 6. But panel B of Table 6 shows that high D/E ratios prior to acquisition cause low ROE while low D/E ratio results in high $\mathrm{ROE}$ but the difference is statistically insignificant. Hence test results for both proxies of performance are statistically insignificant and we fail to obtain sufficient evidence to accept the hypothesis H4 that unutilized debt capacity of acquirer 
firms before M\&A affects negatively post mergers performance.

\begin{tabular}{|c|c|c|c|}
\hline \multicolumn{4}{|c|}{ Table 6: Overconfidence, Panel A:Return on Assets (ROA) } \\
\hline Particulars & Underperforming & Outperforming & Sig. 2-tailed \\
\hline $\begin{array}{l}\text { Acquirer Pre Debt to Equity (D/E) } \\
\text { ratio }\end{array}$ & 53.5070 & 94.5850 & \\
\hline No. of Observations & 40 & 56 & \\
\hline Mean Difference & \multicolumn{2}{|c|}{41.0780} & 0.284 \\
\hline \multicolumn{4}{|l|}{ Panel B: Return on Equity (ROE) } \\
\hline Particulars & Underperforming & Outperforming & Sig. 2-tailed \\
\hline $\begin{array}{l}\text { Acquirer Pre Debt to Equity (D/E) } \\
\text { ratio }\end{array}$ & 81.6268 & 75.3903 & \\
\hline No. of Observations & 32 & 64 & \\
\hline Mean Difference & \multicolumn{2}{|c|}{-6.2365} & 0.810 \\
\hline
\end{tabular}

We employ equation (3) as multivariate analysis for managerial hubris (overconfidence). As shown in Table 8 (Panel A and B), coefficients for D/E ratio for ROA and ROE are statically insignificant. We fail to accept 4th hypotheses that unutilized Debt capacity of acquirer firms before M\&A affects negatively post mergers performance. We do not find sufficient evidence of managerial hubris (overconfidence) that motivate M\&A transactions in Pakistan.

\begin{tabular}{|c|c|c|}
\hline \multicolumn{3}{|l|}{ Table 7 (Panel A): Hubris (Overconfidence) } \\
\hline Dependent Variables: Return on Assets (ROA) & Coefficient & p-values \\
\hline Intercept & -1.709 & 0.009 \\
\hline Acquirer firms' Pre-acquisition D/E ratio & 0.061 & 0.556 \\
\hline Size of Acquisition & 0.061 & 0.606 \\
\hline Tangibility & 0.255 & 0.017 \\
\hline Sales Growth & 0.013 & 0.910 \\
\hline Adjusted $\mathbf{R}^{2}$ & Significance $\mathbf{F}$ & $\mathbf{n}$ \\
\hline 0.046 & $0.081 *$ & 96 \\
\hline \multicolumn{3}{|l|}{ Table 7 (Panel B): Overconfidence } \\
\hline Dependent Variables: Return on Equity (ROE) & Coefficient & p-values \\
\hline Intercept & 1.339 & $0.006^{* * *}$ \\
\hline Acquirer firms' Pre-acquisition D/E ratio & 0.093 & 0.352 \\
\hline Size of Acquisition & -0.316 & $0.006 * * *$ \\
\hline Tangibility & -0.242 & $0.018^{* *}$ \\
\hline Sales Growth & 0.259 & $0.023^{* *}$ \\
\hline Adjusted $\mathbf{R}^{2}$ & Significance $\mathbf{F}$ & $\mathbf{n}$ \\
\hline 0.122 & $0.003^{* * *}$ & 96 \\
\hline \multicolumn{3}{|c|}{$* * * 1 \%$ level of significance, $* * 5 \%$ level of significance, $* 10 \%$ level of significance } \\
\hline \multicolumn{3}{|c|}{$\begin{array}{l}\text { Note: Debt to Equity ratio is Acquirer Debt capacity before acquisition, Target assets in \%ag } \\
\text { of acquirer assets }\end{array}$} \\
\hline
\end{tabular}




\section{Escalation of commitment}

The final behavioral issue discussed in literature review section is an escalation of commitment measured through the change in capital expenditure (CAPEX) during the year -1 to +3 . Test results, reported in Table 8 , are statistically significant at $5 \%$ level for both proxies (ROA \& ROE) of performance and shows that higher growth in capital expenditure causes underperforming M\&A. Put it in other way, firms whom management spend more in long term asset produce negative results in terms of ROA and ROE. We have sufficient evidence to reject fifth hypothesis H5 that M\&A that experience increase in post-M\&As capital expenditure overperform with respect to other M\&A. So it is concluded that management of sample firms of the study are biased due to the escalation of commitment in M\&A deals and post M\&A expenditure. The managers involved in the process to invest further in order avoid loss and try to convert the value-destroying mergers and acquisitions into outperforming mergers and acquisitions.

\begin{tabular}{|c|c|c|c|}
\hline \multicolumn{4}{|c|}{$\begin{array}{l}\text { Table 8: Escalation of Commitment } \\
\text { Panel A: Return on Assets (ROA) }\end{array}$} \\
\hline Particulars & Underperforming & Outperforming & Sig. 2-tailed \\
\hline $\begin{array}{l}\text { Capital Expenditures growth } \\
\text { year }-1 \text { to }+3\end{array}$ & 0.4999 & 0.09483 & \\
\hline No. of Observations & 54 & 36 & \\
\hline Mean Difference & \multicolumn{2}{|c|}{0.405} & $.005^{* *}$ \\
\hline \multicolumn{4}{|c|}{ Panel B: Return on Equity (ROE) } \\
\hline Particulars & Underperforming & Outperforming & $\begin{array}{l}\text { Sig. } 2- \\
\text { tailed }\end{array}$ \\
\hline $\begin{array}{l}\text { Capital Expenditures growth } \\
\text { year }-1 \text { to }+3\end{array}$ & 0.4494 & 0.06338 & \\
\hline No. of Observations & 64 & 26 & \\
\hline Mean Difference & \multicolumn{2}{|c|}{0.3861} & $0.002^{* *}$ \\
\hline
\end{tabular}

Multivariate analysis for escalation of commitment hypothesis is reported in Table 9 employing equation (4). As reported in the table that changes in capital expenditures causes to change the ROE significantly but the relationship with ROA is insignificant. The coefficient of main variables, Capex is statistically significant at $5 \%$ level. Based on these results, our 5th one hypothesis is accepted and suggests that 
managers involved in M\&A deals in Pakistani market seem to be biased of escalation of commitment heuristic. Consequently, it may cause managers to throw good money after bad and may result in underperforming M\&A deals.

Our result is consistent with Shefrin (2007) who reports that managers spend more money on failure for they feel responsible while in success case no feeling of a sense of achievement. A similar interpretation is given by Bazerman \& Moore (2009) about managers' tendency to be a bias of escalation of commitment. This becomes severe when M\&A publicize and managers feel that failure is questioned of their reputation. Results for the control variables show that merger size influences post-M\&A performance. The coefficient of the size of acquisition is negative in every four regressions of ROE and statistically significant. Our results are consistent with prior studies such as Healey et al. (1992), Linn and Switzer (2001), Moeller, Schlingemann and Stulz (2004).

\begin{tabular}{|c|c|c|}
\hline \multicolumn{3}{|l|}{ Table 9 (Panel A): Escalation of commitment } \\
\hline Dependent Variables: Return on Asset (ROA) & Coefficient & p-values \\
\hline Intercept & -1.913 & $0.006^{* * *}$ \\
\hline Changes in Capital Expenditure (CAPEX) & 0.077 & 0.466 \\
\hline Size of Acquisition & 0.051 & 0.679 \\
\hline Tangibility & 0.285 & $0.009 * * *$ \\
\hline Sales Growth & 0.013 & 0.913 \\
\hline Adjusted $\mathbf{R}^{2}$ & Significance $\mathbf{F}$ & $\mathbf{n}$ \\
\hline 0.047 & $0.090 *$ & 96 \\
\hline \multicolumn{3}{|l|}{ Table 10 (Panel B): Escalation of commitment } \\
\hline Dependent Variables: Return on Equity (ROE) & Coefficient & p-values \\
\hline Intercept & 1.476 & $0.004 * * *$ \\
\hline Changes in Capital Expenditure (CAPEX) & -0.196 & $0.052^{*}$ \\
\hline Size of Acquisition & -0.338 & $0.005^{* * *}$ \\
\hline Tangibility & -0.243 & $0.018^{* *}$ \\
\hline Sales Growth & 0.292 & $0.013^{* *}$ \\
\hline Adjusted $\mathbf{R}^{2}$ & Significance $F$ & $\mathbf{n}$ \\
\hline 0.156 & $\mathbf{F} 0.001 * * *$ & 96 \\
\hline \multicolumn{3}{|c|}{ *** $1 \%$ level of significance, $* * 5 \%$ level of significance, $* 10 \%$ level of significance } \\
\hline \multicolumn{3}{|c|}{$\begin{array}{l}\text { Note: Capital Expenditure in \%age of Sales for year }+1 \text { to }+3 \text {, Target assets in } \% \text { age of } \\
\text { acquirer assets }\end{array}$} \\
\hline
\end{tabular}




\section{CONCLUSION}

This study aims at providing financial performance analysis of merger and acquisition (M\&A) in Pakistan using accounting-based measures of performance and explores the impact of agency related issues, like empire building and managerial risk aversion, on post-M\&A performance. The study further examines the possible role of behavioral motives in post-acquisition firm performance.

Empirical results support the presence of empire building motives that may lead managers to underperforming M\&As in Pakistan. This study does not find sufficient evidence to support the managerial risk aversion motives in Pakistani firms that undertake mergers. In nutshell, our analysis of M\&A reveals that industry relatedness has not any significant power to explain the changes in post-M\&A performance. Furthermore, this study does not find evidence regarding the existence of hubris (overconfidence) where managers overestimate their capabilities and turn to reduce the post-merger performance. Finally, results for the escalation of commitment and its consequences on post-M\&A performance supports the hypothesis that managers who are involved in M\&A are influenced by the escalation of committed biases, and that may cause some acquisitions to underperform in some cases.

\section{REFERENCES}

Abdullah, F., Shah, A., \& Khan, S. (2012). Firm Performance and the Nature of Agency Problems in Insiderscontrolled Firms: Evidence from Pakistan. The Pakistan Development Review, 51(4), 161-183

Agrawal, A., Jaffe, J. F., \& Mandelker, G. N. (1992). The Post-Merger Performance of Acquiring Firms: A Re-examination of an Anomaly. The Journal of Finance, 47(4), 1605-1621.

Bazerman, M.H., and Moore, D.A. (2009), Judgment in Managerial Decision Making, John Wiley \& Sons, Inc.,7th edition

Ben-David, I., Graham, J. R., \& Harvey, C. R. (2007). Managerial overconfidence and corporate policies (No. w13711). National Bureau of Economic Research.

Berger, P. G., \&Ofek, E. (1995). Diversification's effect on firm value. Journal of financial economics, 37(1), 39-65.

Brealey, R. A., Myers, S. C., \& Allen, F. (2008). Brealey, Myers, and Allen on Valuation, Capital Structure, and Agency Issues. Journal of Applied Corporate Finance, 20(4), 49-57.

Chatterjee, S. (1992). Sources of value in takeovers: synergy or restructuring-implications for target and bidder firms. Strategic management journal, 13(4), 267-286.

DePamphilis, D. M. (2008). Mergers, acquisitions, and other restructuring activities. Academic Press.

Dimson, E., \& Marsh, P. (1986). Event study methodologies and the size effect: The cases of UK press recommendations. Journal of Financial Economics, 17(1), 113-142.

Doukas, J. A., Travlos, N. G., \& Holmen, M. (2001). Corporate diversification and firm performance: Evidence from Swedish acquisitions. Available at SSRN 250520 
Fatima, T., \& Shehzad, A. (2014). An Analysis of Impact of Merger and Acquisition of Financial Performance

Ferris, S. P., Jayaraman, N., \& Sabherwal, S. (2013). CEO overconfidence and international merger and acquisition activity. Journal of Financial and Quantitative Analysis, 48(01), 137-164.of Banks: A case of Pakistan. Journal of Poverty, Investment, and Development, 5, 29-36.

Ghosh, A. (2001). Does operating performance really improve following corporate acquisitions?. Journal of corporate finance, 7(2), 151-178.

Healy, P. M., Palepu, K. G., \& Ruback, R. S. (1992). Does corporate performance improve after mergers?.Journal of financial economics, 31(2), 135-175.

Hodgkinson, L., \& Partington, G. H. (2008). The Motivation for Takeovers in the UK. Journal of Business Finance \& Accounting, 35(1-2), 102-126.

Houston, J. F., James, C. M., \& Ryngaert, M. D. (2001). Where do merger gains come from? Bank mergers from the perspective of insiders and outsiders. Journal of financial economics, 60(2), 285-331.

Hribar, P., \& Yang, H. (2013). CEO overconfidence and management forecasting. Available at SSRN 929731.

Ismail, T. H., Abdou, A. A. and Annis, R. M., (2010). Exploring Improvements in Post-Merger Corporate Performance- the Case of Egypt. The Icfai University Journal of Business Strategy, 2(3), 171-189

Jensen, M. C. (1986). Agency cost of free cash flow, corporate finance, and takeovers. Corporate Finance, and Takeovers. American Economic Review,76(2).

Jensen, M. C., \&Meckling, W. H. (1976). Agency Costs and the Theory of the Firm. Journal of Financial Economics, 3(4), 305-360.

Jovanovic, B., \&Braguinsky, S. (2002). Bidder discounts and target premia in takeovers (No. w9009). National Bureau of Economic Research.

Kalra, R. (2013). Mergers and Acquisitions: An Empirical Study on the Post-Merger Performance of Selected Corporate Firms in India. The IUP Journal of Business Strategy, 10(4), 7-67.

Kruse, T.A., Park, H.Y., Park, K. and Suzuki, K. (2002), Post-Merger Corporate Performance in Japan, SSRN Working Paper, April 15th, pp. 1-32

Kumar, R. (2009). Post-merger corporate performance: an Indian perspective. Management Research News, 32(2), 145-157.

Laamanen T, Keil T. 2008. Performance of serial acquirers: Toward an acquisition program perspective. Strategic Management Journal 29(6): 663-672.

Lau, B., Proimos, A., \& Wright, S. (2008). Accounting measures of operating performance outcomes for Australian mergers. Journal of Applied Accounting Research, 9(3), 168-180.

Linn, S. C., \& Switzer, J. A. (2001). Are cash acquisitions associated with better post-combination operating performance than stock acquisitions?. Journal of Banking \& Finance, 25(6), 1113-1138.

Malmendier, U., \& Tate, G. (2008). Who makes acquisitions? CEO overconfidence and the market's reaction. Journal of Financial Economics,89(1), 20-43.

Mantravadi, D. P., \& Reddy, A. V. (2008). Post-merger performance of acquiring firms from different industries in India. International Research Journal of Finance and Economics, (22).

Martynova, M., Oosting, S., \& Renneboog, L. (2006). The long-term operating performance of European mergers and acquisitions. ECGI-Finance Working Paper, (137).

Mishra, C. S., Randøy, T., \& Jenssen, J. I. (2001). The effect of founding family influence on firm value and corporate governance. Journal of International Financial Management \& Accounting, 12(3), 235259.

Morck, R., Shleifer, A. and Vishny, R.W. (1990), Do Managerial Objectives Drive Bad Acquisitions?, The Journal of Finance, vol. XLV, no.1, March 1990, pp. 31-48

Murphy, K. J. (1985). Corporate performance and managerial remuneration: An empirical analysis. Journal of accounting and economics, 7(1), 11-42.

Nguyen, H. T., Yung, K., \& Sun, Q. (2012). Motives for Mergers and Acquisitions: Ex -Post Market Evidence from the US. Journal of Business Finance \& Accounting, 39(9-10), 1357-1375.

Parrino, J. D., \& Harris, R. S. (1999). Takeovers, Management Replacement, and Post-Acquisition Operating Performance: Some Evidence from the 1980s. Journal of Applied Corporate Finance,11(4), 88-96.

Pazarskis, M., Vogiatzogloy, M., Christodoulou, P., \&Drogalas, G. (2006). Exploring the improvement of corporate performance after mergers-the case of Greece. International Research Journal of Finance and Economics, 1(6), 184-192. 
Powell, R. G., \& Stark, A. W. (2005). Does operating performance increase post-takeover for UK takeovers? A comparison of performance measures and benchmarks. Journal of Corporate Finance, 11(1), 293-317

Ramaswamy, K. P., \&Waegelein, J. F. (2003). Firm financial performance following mergers. Review of Quantitative Finance and Accounting, 20(2), 115-126.

Randøy, T., \&Goel, S. (2003). Ownership structure, founder leadership, and performance in Norwegian SMEs: implications for financing entrepreneurial opportunities. Journal of Business Venturing, 18(5), 619637.

Roll, R. (1986). The hubris hypothesis of corporate takeovers. Journal of business, 197-216.

Servaes, H. (1991). Tobin's Q and the Gains from Takeovers. The Journal of Finance, 46(1), 409-419.

Sharma, D. S., \& Ho, J. (2002). The impact of acquisitions on operating performance: Some Australian evidence. Journal of Business Finance \& Accounting, 29(1-2), 155-200.

Shefrin, H. (2007), Behavioral Corporate Finance - Decisions that Create Value, McGraw-Hill, 1st edition

Sinha, N., Kaushik, K. P., \&Chaudhary, T. (2010). Measuring post-merger and acquisition performance: An investigation of select financial sector organizations in India. International Journal of Economics and Finance, 2(4), p190.

Sudarsanam, P. S., \&Sudarsanam, P. S. (1995). The essence of mergers and acquisitions (Vol. 230). Hemel Hempstead: Prentice Hall.

Switzer, J. A. (1996). Evidence on real gains in corporate acquisitions. Journal of Economics and Business, 48(5), 443-460.

Trivedi, J. C. (2013). A Study on Pre \& Post Performance Evaluation of Merger and Acquisition of Top Companies of BSE and NSE. SIES Journal of Management, 9(2), 3-15

Usman, A., Khan, M. K., A. Wajid, and M. I. Malik, M. I. (2005). Investigating the Operating Performance of Merged Companies in Textile Sector of Pakistan. Asian Journal of Business and Management Sciences, 1(10), 11-16

Yeh, T. M., \& Hoshino, Y. (2002). Productivity and operating performance of Japanese merging firms: Keiretsurelated and independent mergers. Japan and the World Economy, 14(3), 347-366 